\title{
CHANGE MANAGEMENT PRACTICES FOR ADOPTING NEW TECHNOLOGIES IN THE DESIGN AND CONSTRUCTION INDUSTRY
}

SUBMITTED: March 2020

REVISED: April 2020

PUBLISHED: June 2020

EDITOR: Bimal Kumar

DOI: $10.36680 /$ j.itcon.2020.019

Omar Maali, Graduate Student,

Department of Civil, Environmental and Architectural Engineering, University of Kansas, KS, USA; Maali@ku.edu

Brian Lines, Associate Professor,

Department of Civil, Environmental and Architectural Engineering, University of Kansas, KS, USA; Brianlines@ku.edu

Jake Smithwick, Assistant Professor,

Department of Engineering Technology and Construction Management, University of North Carolina, NC, USA; Jake.smithwick@uncc.edu

Kristen Hurtado, Research Professor,

Del E. Webb School of Construction, Arizona State University, AZ, USA;

Kristen.Hurtado@asu.edu

Kenneth Sullivan, Professor,

Del E. Webb School of Construction, Arizona State University, AZ, USA;

Kenneth.Sullivan@asu.edu

SUMMARY: The architecture, engineering, and construction (AEC) industry has often been accused of being slow to adopt change. Yet the breadth of available technology solutions in the modern AEC industry continues to grow. Companies therefore must be adept at organizational change management; otherwise, the full benefits of technology solutions may never be realized when a company fails to achieve successful change adoption. The objective of this study was to identify the relationships between specific change management practices and organizational adoption of new technology solutions. An industry-wide approach was taken, wherein an online survey methodology was used to collect 167 cases of organization-wide change from AEC firms across the United States and Canada. The method of analysis included a correlation analysis between change management practices and change adoption. Reliability testing and principal components analysis were used to extract a single construct measure of change adoption. Rank-based nonparametric testing investigated if there are statistically significant differences between different groups of participants and technologies. Results include a rank-order of specific change management practices most associated with successful technology adoption. Change-agent effectiveness, measured benchmarks, realistic timeframe, and communicated benefits are the four change management practices that had the strongest association strength with successful change adoption. The discussion addresses how these leading change management practices compare with previous literature. Also, it was found that organization type and job position were correlated with the levels of change-adoption success compared to other listed factors. This study contributes an industry-wide view of change management practices within the context of technology-based change adoption and may assist practitioners to better manage technology adoptions in their organizations.

KEYWORDS: IT, Adoption, Technology, Best Practices, Organizational Change Management, Architecture, Engineering and Construction.

REFERENCE: Omar Maali, Brian Lines, Jake Smithwick, Kristen Hurtado, Kenneth Sullivan (2020). Change management practices for adopting new technologies in the design and construction industry. Journal of Information Technology in Construction (ITcon), Vol. 25, pg. 325-341, DOI: 10.36680/j.itcon.2020.019

COPYRIGHT: () 2020 The author(s). This is an open access article distributed under the terms of the Creative Commons Attribution 4.0 International (https://creativecommons.org/licenses/by/4.0/), which permits unrestricted use, distribution, and reproduction in any medium, provided the original work is properly cited. 


\section{INTRODUCTION}

In recent years, the use of new technologies in the AEC industry is increasing due to market pressure to improve productivity, reduce costs, enhance safety, and increase sustainability (Loosemore, 2014). Examples of technology innovations that have been introduced in the AEC industry include building information modelling (BIM), mobile technology, scanning technology, sensor technology, virtual reality, augmented reality, safety monitoring, unmanned aerial vehicles, remote-controlled construction equipment, internet of things, and 3D printing. Technology innovations in the AEC industry will continue to be developed and to evolve because the benefits of technologies are well recognized. However, the adoption of technologies in the industry is typically slow when compared to other industries (Gholizadeh et al, 2018). Further, there are variations in the degree of technology adoption achieved between companies due to the different change management practices they employ (Lee and $\mathrm{Yu}, 2016)$.

Adopting a new technology is considered an organizational change since the adoption will affect the processes and protocols in the organization. In this context, organizational change management (OCM) is defined as the steps to implement practices that are different from the organization's current practices, with the intent to achieve organization-wide goals (Burnes, 2009). The AEC industry is not considered an industry that fosters innovations; some sources have asserted that the reluctance to adopt innovations is a reason for the decline in the industry's productivity over 50 years (Crew, 2017). Previous studies of technology adoption in the AEC industry-although primarily focused on investigating technological functionality and operational benefits-have consistently identified OCM elements as being major barriers to adopting technologies (Ahn et al. 2016, Lee and Yu 2016). The industry has an interest in establishing practices for managing technology adoption in the context of organizational change, so that implementation barriers can be overcome.

\section{LITERATURE REVIEW}

An interdisciplinary approach was used to understand key practices in OCM for technological innovations. The collected review was divided into two sections. The first section reviews common OCM practices in the organizational behaviour literature, in the AEC industry, and specifically for technology adoption in the AEC industry. The second section reviews specific OCM practices that were commonly identified in the literature.

\subsection{OCM in the organizational behaviour literature}

Lewin (1947), an early researcher on OCM, proposed three phases of change implementation: unfreezing, moving, and refreezing. Lewin's research indicated that organizational change can be divided into steps to successfully adopt change. Several models of recommended OCM practices were proposed throughout the literature (Burnes 2009, Kotter 1995, Luecke 2003). According to these models, a well-planned process is needed to successfully implement change. These models commonly recommended practices such as using change agents to lead the change process, communicating the change vision, monitoring the change progress, obtaining the commitment of top management, and providing change-related training for employees. However, direct application of these models in the AEC industry is limited because they were not designed specifically for the AEC industry (Lines and Smithwick 2019).

\subsection{OCM in the AEC industry}

OCM practices in the AEC industry are accompanied by several barriers to change adoption because of the nature of the industry (Harty 2005, Harty 2008, Lines et al. 2015). Studies regarding change implementation in the AEC industry have predominantly focused on one type of change innovation, such as alternative project delivery and other modern methods of construction, such as lean construction, Six Sigma, and risk management. Technology adoption has also been a theme, as described in the next sub-section. The literature has mainly focused on the technical aspects of adopting the change rather than management practices in the context of OCM (Lines and Smithwick 2019). Limited studies have investigated OCM practices in the AEC industry and provided best practices for managing the change process to achieve maximum benefits (Erdogan et al, 2014). 


\subsection{OCM for adopting technologies in the AEC industry}

Researchers have investigated practices in technology innovation, diffusion, and implementation in various contexts, such as technology in general, specific types of technology, specific types of technology in specific industry subsectors, technology in specific countries, and technology in specific projects.

Slaughter (2000) emphasized that to improve the technological capacity in the construction industry, an innovation management system is needed. Researchers have studied innovations to provide better innovation management models (Ercan, 2019). Researchers have identified factors promoting and preventing the diffusion and adoption of technology in the AEC industry (Gan et al. 2019, Sepasgozar et al. 2018). Researchers have also studied several types of sensor technologies are used to improve safety at construction sites, (Zhang et al. 2019a, Zhang et al. 2019b). And Seo et al. (2018) examined the application of using unmanned aerial vehicles, also known as drones, to improve inspection process for a bridge located in South Dakota.

Smart systems, such as planning software and design software, are management tools that are helping the construction industry improve its quality (Delgado-Hernandez et al, 2017). Researches have studied the applications of smart systems, such as the use virtual reality and augmented reality for site monitoring, safety training, facilities management, and quality management.

One of the widely researched smart systems is BIM. Researchers have studied BIM's effectiveness and functions (Hwang et al. 2019, Liu, et al. 2017); diffusion of BIM (Gholizadeh et al, 2018) and the impacts and applications of BIM implementation on other process, such as integrated project delivery (Chang et al, 2017); lean construction and green buildings (Ahuja et al, 2018). Critical success factors for BIM implementation have been clearly identified throughout the literature from 2005 to 2015 (Antwi-Afari et al, 2018). Other BIM studies examined implementation acceptance, risks and barriers (Zhou et al. 2019, Lee and Yu 2016), and differences in maturity level of adoption between adopters (Chong et al, 2016).

However, the literature of technology adoption in the AEC industry has primarily investigated the technological functionality and benefits of the adoption, with a limited primary focus on the OCM consideration. Also, the research designs of existing literature are predominantly limited to an individual type of adopted technology or capture a limited number of organizational change cases in their data samples.

\section{OCM PRACTICES}

The literature review identified seven OCM practices in which were repetitively recommended throughout the organizational change literature. The seven OCM practices also aligned with practices used in two previous studies of OCM practices in the AEC industry (Lines and Smithwick 2019, Lines and Vardireddy 2017). These practices are discussed in the following subsections.

\subsection{Senior-leadership commitment}

An important driver of successful change adoption identified in the literature is the involvement of senior leadership. Before the adoption of any change, senior leaders should justify the purpose and appropriateness of the proposed change (Beer and Eiesentat, 1996). Senior leaders should be committed throughout the entire changeadoption process (Armenakis et al, 1999) to support the progress of the change in the organization (Emiliani and Stec, 2005). In the AEC industry, a lack of senior-level support is a critical hindrance to implementing enterprise risk management (Zhao et al, 2015). In a study that investigated critical success factors for BIM implementation in developing countries, effective leadership was found to be one of the most significant drivers of success in 96 construction firms (Ozorhon and Karahan, 2017). A study about obstacles to implementing information and communication technologies (ICT) showed the importance of managers providing support (Peansupap and Walker, 2006). Liao et al. (2018) reported that the early involvement of key stakeholders and primary participants counters obstacles to implementing BIM and enhances the adoption of change in building projects. Other researchers have stated the crucial role that management support plays to the adoption of BIM (Cheng and Teizer 2013, Gu et al. 2010, Lu et al. 2015, Xu et al. 2014). 


\subsection{Training resources}

A major obstacle to successfully implementing change is not providing appropriate change-related training to employees (Alvesson 2002, Galpin 1996, Schneider et al. 1994). To implement and achieve the full potential of BIM, the AEC industry need to invest in training (Chang et al, 2017). Providing change-related training has been shown as an important factor supporting successful adoption of ICT (Lu et al. 2015, Peansupap and Walker 2006) and BIM (Ahn et al. 2016, Ozorhon and Karahan 2017).

\subsection{Communicating the Benefits of Change}

To avoid resistance to change, the benefits of the change should be communicated to the employees (Bourne et al, 2002). The disadvantages of not implementing the change should also be communicated (Cameron and Quinn, 1999). A study across the AEC industry was conducted to investigate potential causes of the digital divide in BIM adoption. The researchers found that when employees lack an understanding of the benefits of implementing BIM, they are more likely to resist the change (Ayinla and Adamu, 2018). In another study on BIM implementation, one of the listed barriers was uncertainty about the benefits of BIM implementation (Zhou et al, 2019). Peansupap and Walker (2006) noted that one of the obstacles to change at the organizational level is the failure to identify clear benefits of using ICT. Arayici et al. (2011) and Peansupap and Walker (2006) stressed the importance of communicating the benefits of change to employees.

\subsection{Establishment of a realistic timeframe for change adoption}

The benefits of strategic long-term planning instead of short-term planning were highlighted by Garratt (1999) and Tatum (1989). Smollan (2011) noted that employees may resist change if they believe that managers are requiring the change at an impractical time. Hong et al. (2019) identified the absence of long-term BIM implementation plans as an organizational barrier to implementing BIM. Other researchers have reported that an obstacle to implementing change involves underestimating the resources and time required for employee to learn and accomplish the change (Loosemore and Cheung 2015, Li and Becerik-Gerber 2011, Peansupap and Walker 2006, Sullivan 2011, Tan et al. 2012).

\subsection{Change agent effectiveness}

Change agents are members of an internal team that guides the transition; change agents are known as the "internal champions of change" (Hunsucker and Loos 1989, Kanter 1983). Change agents have one of the most important roles during change implementation (Wolpert, 2010). Organizations should assign individuals to be change agents, giving them responsibility to lead the change. Members of the change agent team should be available to provide support before and during the change (Covin and Kilmann 1990, Schweiger and DeNisi 1991). In a study comparing BIM acceptance in Korea and the United States, the researchers found that BIM acceptance can be increased in Korean companies by organizing a group of employees who are open to adopting new technologies (Lee and Yu, 2016). Ahn et al. (2016) suggested that BIM adoption can be enhanced when a company creates a department with clear organizational goals related to BIM implementation. Gu and London (2010) stated that to facilitate BIM adoption in the AEC industry, companies need to have teams that have been trained and that are dedicated to supporting BIM implementation.

\subsection{Establish clear and measured benchmarks of change progress}

Establishing clear benchmarks of the required change outcomes and actively measuring them throughout the change process is an important strategy for building change momentum (Lines and Vardireddy, 2017). Creating short-term millstones and celebrating it, will recognize and reward employees who been actively involved in the change (Kotter, 1995). In BIM adoption, a proper list of benchmarks is very important to evaluate BIM performance and to point the future directions (Liu et al, 2017). Lack of immediate benefits and performance improvements are barriers for BIM implementation (Eadie et al. 2013, Lee et al. 2015). Lines and Smithwick (2019) stated that measuring performance benchmarks have several advantages, including measuring if the change is being successful and help in building change momentum. 


\subsection{Workload adjustments to support the adoption}

Learning and applying new practices and processes are inevitable aspects of change implementation. Employees involved in change implementation will typically have change-related trainings, meetings, and other activities added to their workloads. Smollan (2011) observed that employees resist change when they experience unfavourable outcomes, such as work overload. In the AEC industry, which is focused on cost and time, investment is required to successfully implement change (Chang et al, 2017). Employees' time is one of the investments that should be considered when implementing change. Peansupap and Walker (2006) found that two of the obstacles to ICT implementation are the time available to learn the new information and the time available to share information. Also, the researchers mentioned that managers have little time to mentor employees and encourage them to implement the change. Peansupap and Walker (2006) added that employees may become frustrated about implementing the change because of the lack of time to learn about the change and how to resolve questions that arise. To reduce employee resistance to change, organizations should provide enough time for employees to learn needed information and solutions.

\section{SUCCESSFUL CHANGE ADOPTION}

Successful adoption of change is the goal of any change initiative. This goal can be measured in multiple ways, such as by using benchmarks and defining objectives of the change (e.g., lowering resource cost). The appropriate measurement depends heavily on the type of change. Three measurements of successful adoption of technology in the AEC industry have been identified in studies on electrical contractors in the United States (Lines and Smithwick, 2019) and internationally (Lines and Vardireddy, 2017). The measurements used in this study regard whether the organizational change was adopted as intended, whether the organizational change resulted in benefits, and whether the organizational change is sustainable with the organization's long-term operations.

\section{METHODOLOGY}

\subsection{Research objectives and anticipated contribution}

The overall objective of this study was to understand the relationships between leading OCM practices and the adoption of technologies in the AEC industry. To achieve the study objectives, a survey questionnaire was used to collect 167 cases of organizational change within the context of technology adoption. The questionnaire's unit of measure was designed such that each data point represented an entire organizational change case that occurred within an organization. This study contributes an industry-wide view of change management practices specifically within the context of technology-based organizational change adoption, which may assist practitioners to better understand and manage technology adoption process in their organizations.

\subsection{Survey design, distribution and data collection}

The survey was designed to gather responses where each response represented an organizational change initiative that was implemented by an organization in the AEC industry. Participants were asked to identify successful or unsuccessful technology change that their firms had experienced. The survey was designed using an online tool that helped in reaching participants via email distribution. Then the survey was tested by distributing it to 25 participants via email. The pilot survey participants recommended making minor changes, which were incorporated into the final version of the survey.

The survey had two sections. In the first section, participants were asked to identify a technology change that their firms had experienced. The first section also contained statements regarding the independent and dependent variables (seven change management practices and three change adoption measurements). The responses to these statements were based on a 7-point Likert-type scale (strongly agree, agree, somewhat agree, neither agree nor disagree, somewhat disagree, and strongly disagree). The Likert scale was developed to measure people's agreement or disagreement with a statement (Likert, 1932). Such ordinal scales use fixed responses to measure the opinions and attitudes of respondents (Bowling, 1997, Burns and Grove, 1997). The second section of the survey was designed to collect information about the respondents' demographics, including organization sector, organization type, respondent's job position, respondent's years of professional experience, and respondent's generational affiliation. 
A wide range of architecture, engineering, construction, and owner representatives were targeted for participation in the survey. Email addresses were gathered from private, public, and professional groups and organizations in the AEC industry across North America. More responses were obtained by using a snowball technique. In total, 167 individuals responded to the survey, representing a wide spectrum of organizations in the AEC industry. Each respondent provided information about a single case of technology adoption.

\subsection{Research hypotheses and definition of variables}

To achieve research objectives, three hypotheses were developed. The focus of the hypotheses is on the relationships between OCM practices for adopting technologies and the success of the change adoption.

Hypothesis 1 is a combination of seven sub-hypotheses, each of which examines the relationship between a dependent variable (the change adoption variables) and one of seven independent variables (OCM variables). Definitions of the seven OCM practices along with multiple change adoption measurements were based on the OCM literature and are listed in Table 1. Change-adoption construct (CAC) is an obtained variable which encompasses three dependent variables measures successful change adoption: overall adoption achieved, the longterm sustainability, and the benefits achieved. The seven sub-hypotheses (H1A-H1G) of Hypothesis 1 are graphically shown in Fig. 1. Each hypothesis examines the relation between the effective use of one OCM practice and change adoption construct. Each of the null hypotheses state that the effective use of that OCM practice is not related with successful change adoption of technology.

\section{TABLE 1: Definition of variables}

\begin{tabular}{ll}
\hline OCM Variables & Definition \\
\hline Senior-leadership commitment & $\begin{array}{l}\text { The organization's senior leaders were committed to making the change a success } \\
\text { (i.e., they "walked the talk"). }\end{array}$ \\
Training resources & $\begin{array}{l}\text { Employees had a clear understanding of the action steps for how to implement the } \\
\text { change in their job functions. }\end{array}$ \\
Communicated benefits & $\begin{array}{l}\text { Employees had a clear understanding of how the change would benefit them in } \\
\text { their job functions. }\end{array}$ \\
Realistic timeframe & $\begin{array}{l}\text { The speed at which the organization implemented the change was appropriate. } \\
\text { The change agents (transition team) responsible for managing the change in the } \\
\text { organization were effective. }\end{array}$ \\
Measured benchmarks & $\begin{array}{l}\text { The organization established clear benchmarks to measure the success of the } \\
\text { change. }\end{array}$ \\
Adjusted workload & $\begin{array}{l}\text { The organization's leaders appropriately adjusted staff members' workloads so } \\
\text { they could focus on implementing the change. }\end{array}$ \\
\hline Change Adoption Variables & $\begin{array}{l}\text { Definition } \\
\text { Overall adoption achieved }\end{array}$ \\
$\begin{array}{l}\text { The organizational change was successfully adopted in the organization's } \\
\text { operations as intended. }\end{array}$ \\
The organization achieved benefits through implementing the change. \\
Sustainability Long-Term
\end{tabular}




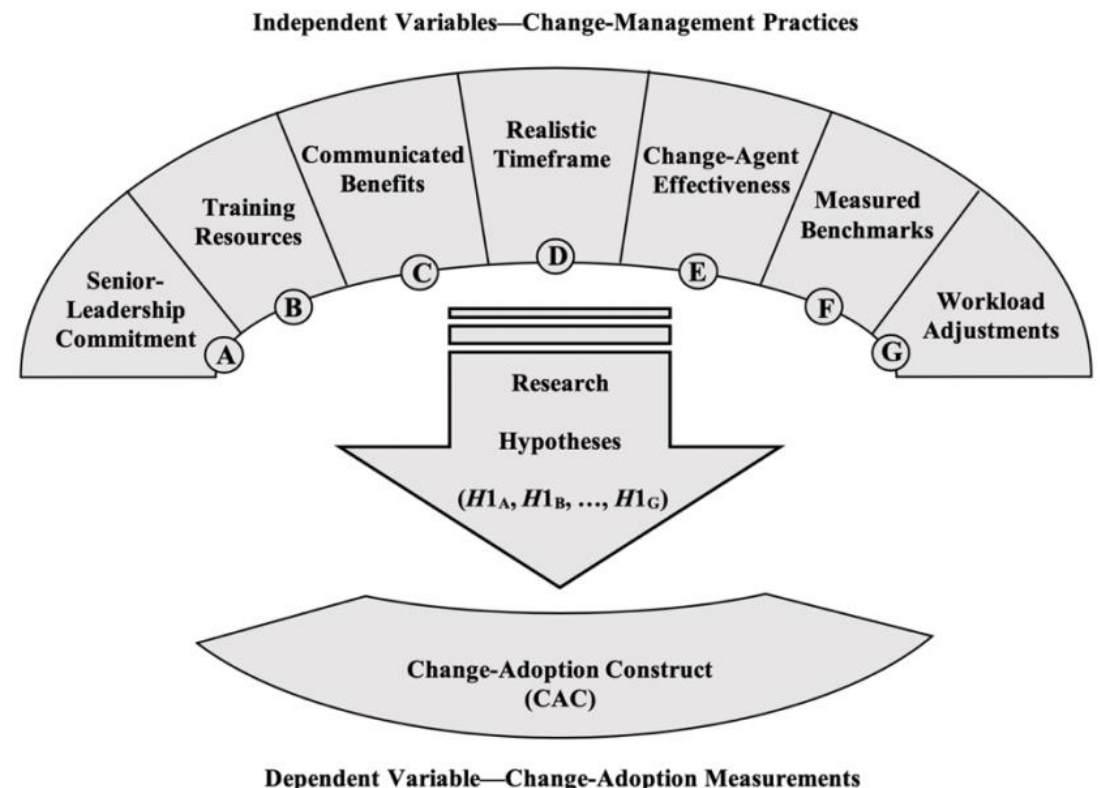

\section{FIG 1. Graphical summary of research hypotheses}

Hypothesis 2 contains two sub-hypotheses (H2A and $\mathrm{H} 2 \mathrm{~B}$ ), for the purpose of studying differences in successful change-adoption levels (CAC) between groups of adopted technology for two categories of adopted technology listed in Table 2. H2A examines adopted technology functions (business-related software, project-related software, and physical technology tools). H2B examines technology characteristics (technology that replaces manual processes, designated as "new technology," as opposed to technology that replaces pre-existing technology, designated as a "replacement or upgrade").

\section{TABLE 2. Definitions of Adopted Technology Categories}

\begin{tabular}{|c|c|}
\hline Technology Function & Example of Technology \\
\hline Business-related software & $\begin{array}{l}\text { The software affected employees and tasks at the business level of the } \\
\text { organization (e.g., enterprise resource planning, asset management, data } \\
\text { management, document management, data analysis, payroll automation, time } \\
\text { management, operating platforms, communication). }\end{array}$ \\
\hline Project-related software & $\begin{array}{l}\text { The software affected employees and tasks at the project level of the organization } \\
\text { (e.g., project management, facility management, cloud-based project } \\
\text { documentation, design software, BIM, 4D, online takeoff, estimations, project } \\
\text { planning). }\end{array}$ \\
\hline Physical technology tools & $\begin{array}{l}\text { Technology tools "Hardware", such as the use of (drones, smartphones, tablets, } \\
\text { tracking sensors, movements sensors, GPS sensors and scanning tools for virtual } \\
\text { reality) }\end{array}$ \\
\hline Technology Characteristic & Definition \\
\hline $\begin{array}{l}\text { Technology that replaces manual } \\
\text { processes (New technology) }\end{array}$ & $\begin{array}{l}\text { The company implemented a technology to replace a manual process (e.g., } \\
\text { replaced a pencil-and-paper process with a technological process). }\end{array}$ \\
\hline $\begin{array}{l}\text { Technology that replaces other } \\
\text { technology (Replacement or upgrade) }\end{array}$ & $\begin{array}{l}\text { The company replaced or upgraded an existing technology (e.g., switched from } \\
\text { one software program to a newer one). }\end{array}$ \\
\hline
\end{tabular}

Regarding Respondent demographics, Hypothesis 3 is divided into five sub-hypotheses (H3A to H3E), one for each demographic category, to study differences in successful change adoption levels (CAC) among groups in a category. $\mathrm{H} 3 \mathrm{~A}$ examines the organization sector category, $\mathrm{H} 3 \mathrm{~B}$ examines the organization type category, $\mathrm{H} 3 \mathrm{C}$ examines the hierarchical position category, $\mathrm{H} 3 \mathrm{D}$ examines the years of professional experience category, and $\mathrm{H} 3 \mathrm{E}$ examines the generational affiliation category. The groups in each demographic category are listed in Table 3. 
TABLE 3. Respondent Demographics

\begin{tabular}{|c|c|}
\hline Demographic Category & Examples \\
\hline Sector type & The organization's sector is either public or private. \\
\hline Organization type & $\begin{array}{l}\text { The organization performs as an owner; engineering, procurement, and } \\
\text { construction (EPC); subcontractor; architect/engineering consultant; or other } \\
\text { type. }\end{array}$ \\
\hline Hierarchical position & $\begin{array}{l}\text { The respondent's job position in the organization is senior executive, vice } \\
\text { president, regional manager, project lead, team member, or another position. }\end{array}$ \\
\hline Years of professional experience & $\begin{array}{l}\text { The respondent has been in the industry for less than } 10 \text { years, } 10-19 \text { years, } 20 \\
29 \text { years, } 30 \_39 \text { years, or } 40 \text { or more years. }\end{array}$ \\
\hline Generational affiliation & $\begin{array}{l}\text { The respondent is a baby boomer (1946-1964), a member of generation } X \\
(1965-1978) \text {, or a member of generation Y (1979-1997). }\end{array}$ \\
\hline
\end{tabular}

\subsection{Data sample}

In total, 167 individuals responded to the survey, representing a wide spectrum of organizations in the AEC industry. Each respondent provided information about a case of technology adoption. Table 4 provides data sample summary with reference to respondents' demographics and types of adopted technology as reported by the respondents.

TABLE 4. Data sample summary

\begin{tabular}{|c|c|c|}
\hline \multicolumn{3}{|l|}{ Respondents' Demographics } \\
\hline Organizational Sector & Frequency & Percentage \\
\hline Public & 64 & $38.3 \%$ \\
\hline Private & 103 & $61.7 \%$ \\
\hline Organization Type & Frequency & Percentage \\
\hline Owner/operator & 47 & $28.1 \%$ \\
\hline EPC/general contractor & 13 & $7.8 \%$ \\
\hline Subcontractor/specialty contractor & 54 & $32.3 \%$ \\
\hline Architecture/engineering consultant & 22 & $13.2 \%$ \\
\hline Facilities management and operation & 12 & $7.2 \%$ \\
\hline Other/no answer & 19 & $11.4 \%$ \\
\hline Job Position & Frequency & Percentage \\
\hline Senior executive/vice president & 28 & $16.8 \%$ \\
\hline Regional manager/director / local office supervisor & 54 & $32.3 \%$ \\
\hline Project members/crew members & 38 & $22.8 \%$ \\
\hline Other/no answer & 47 & $28.1 \%$ \\
\hline Years of Professional experience & Frequency & Percentage \\
\hline Less than 10 years & 12 & $7.2 \%$ \\
\hline $10-19$ years & 17 & $10.2 \%$ \\
\hline $20-29$ years & 60 & $35.9 \%$ \\
\hline $30-39$ years & 44 & $26.3 \%$ \\
\hline 40 or more years & 22 & $13.2 \%$ \\
\hline Unknown/no answer & 12 & $7.2 \%$ \\
\hline Generational Affiliation & Frequency & Percentage \\
\hline Baby boomer (born 1946-1964) & 31 & $18.6 \%$ \\
\hline Generation X (born 1965-1978) & 28 & $16.8 \%$ \\
\hline Generation Y (born 1979-1997) & 13 & $7.8 \%$ \\
\hline Unknown/no answer & 95 & $56.9 \%$ \\
\hline \multicolumn{3}{|l|}{ Technology Categories } \\
\hline Technology Function & Frequency & Percentage \\
\hline Business-related software & 75 & $44.9 \%$ \\
\hline Project-related software & 60 & $35.9 \%$ \\
\hline Hardware technology & 15 & $9.0 \%$ \\
\hline Unknown/no answer & 17 & $10.3 \%$ \\
\hline Technology Characteristics & Frequency & Percentage \\
\hline New technology & 55 & $33.5 \%$ \\
\hline Replacement or upgrade & 56 & $32.9 \%$ \\
\hline Unknown/no answer & 56 & $33.5 \%$ \\
\hline
\end{tabular}




\subsection{Method of Analysis}

First, Cronbach's alpha was used to measure the underlying construct of the three dependent variables (overall adoption achieved, sustainability long-term, and benefits achieved). Cronbach's alpha ( $\alpha$ ) is used to measure the reliability or internal consistency for a set of multiple test items (DeVellis, 2003). Second, Principle Component Analysis (PCA) was performed to produce one dependent variable that represents the three change-adoption variables. The resulting dependent variable, the CAC, was used in addition to the three individual dependent variables. Third, to test Hypothesis 1, Spearman's rank-order test was performed to measure the bivariate relationship between each independent variable of the seven OCM practices and the produced dependent variable $\mathrm{CAC}$ as the change-adoption measurement. Spearman's rank-order correlation is a nonparametric test that is used to measure direction and degree of association between two variables measured using ordinal scale (Spearman, 1904). Fourth, to test both Hypothesis 2 and Hypothesis 3, the Kruskal-Wallis H test and the Mann-Whitney U test were performed to determine whether there were any differences in the levels of change-adoption success based on technology function, technology characteristic, sector type, organization type, hierarchical position, years of professional experience, and generational affiliation.

\section{RESULTS}

\subsection{Internal Reliability of Change Adoption Measurements and PCA}

The results of Cronbach's alpha test indicated there was high internal consistency among the three individual dependent variables. Cronbach's alpha value of 0.876 was above the acceptable threshold of 0.7 (DeVellis, 2003). The suitability of PCA was assessed prior to the analysis. Inspection of the correlation matrix showed that all variables had a correlation coefficient greater than 0.3. The overall Kaiser-Meyer-Olkin (KMO) measure was 0.729 , with all individual KMO measures greater than 0.6. A KMO value of 0.729 is classified as good, according to Kaiser's (1974) classification of measure values. Bartlett's test of sphericity was statistically significant ( $p$ $<$.0005), indicating that the data was likely factorizable. Visual inspection of scree plot indicated that one component should be retained (Cattell, 1966). In addition, the one-component solution met the interpretability criterion. As such, PCA revealed one component that had an eigenvalue greater than 1, explaining $80 \%$ of the total variance. The extracted component was named the change adoption construct (CAC).

\subsection{Bivariate Relationships between OCM Practices and Change Adoption}

Spearman's rank-order test was performed to measure the bivariate relationship between each OCM practice and CAC. Preliminary analysis (involving visual inspection of scatterplots) showed the relationships to be monotonic. The results of Spearman's rank-order test regarding nonparametric correlation are presented in Table 5. All correlations between OCM practices and CAC were statistically significant, found at the $99 \%$ confidence interval. A strong positive correlation existed with each of change-agent effectiveness $\left(\mathrm{r}_{\mathrm{s}}=0.653, p<0.0005\right)$, measured benchmarks $\left(\mathrm{r}_{\mathrm{s}}=0.626, p<0.0005\right)$, realistic timeframe $\left(\mathrm{r}_{\mathrm{s}}=0.618, p<0.0005\right)$, and communicated benefits $\left(\mathrm{r}_{\mathrm{s}}=\right.$ $0.523, p<0.0005)$. While a modest positive correlation existed with change-related training $\left(\mathrm{r}_{\mathrm{s}}=0.485, \mathrm{p}<\right.$ $0.0005)$, senior-leadership commitment $\left(\mathrm{r}_{\mathrm{s}}=0.435, p<0.0005\right)$, and workload adjustments $\left(\mathrm{r}_{\mathrm{s}}=0.419, p<0.0005\right)$. Interpretation of association strength was based on guidelines by Field (2009). The correlations between OCM practices and the CAC in terms of respondents' demographics and types of adopted technology are shown in Table 6.

TABLE 5. Spearman's correlation of independent and dependent variable. All correlations are significant at the 0.01 (2-tailed) level

\begin{tabular}{|c|c|c|c|c|c|c|c|c|}
\hline ID & Variable & A & $\mathrm{B}$ & $\mathrm{C}$ & $\mathrm{D}$ & $\mathrm{E}$ & $\mathrm{F}$ & $\mathrm{G}$ \\
\hline A & Senior-leadership commitment & 1.000 & - & - & - & - & - & - \\
\hline B & Training resources & 0.436 & 1.000 & - & - & - & - & - \\
\hline $\mathrm{C}$ & Communicated benefits & 0.376 & 0.621 & 1.000 & - & - & - & - \\
\hline $\mathrm{D}$ & Realistic timeframe & 0.431 & 0.546 & 0.548 & 1.000 & - & - & - \\
\hline $\mathrm{E}$ & Measured benchmarks & 0.476 & 0.612 & 0.510 & 0.510 & 1.000 & - & - \\
\hline $\mathrm{F}$ & Change-agent effectiveness & 0.498 & 0.592 & 0.534 & 0.625 & 0.657 & 1.000 & - \\
\hline G & Workload adjustments & 0.530 & 0.520 & 0.425 & 0.414 & 0.529 & 0.495 & 1.000 \\
\hline 1 & CAC & 0.435 & 0.485 & 0.523 & 0.618 & 0.626 & 0.653 & 0.419 \\
\hline
\end{tabular}


TABLE 6. Summary of correlations between OCM practices and CAC in terms of respondents' demographics and types of adopted technology

\begin{tabular}{|c|c|c|c|c|c|c|c|}
\hline Category & $\begin{array}{l}\text { Sr. leader. } \\
\text { commit. }\end{array}$ & $\begin{array}{l}\text { Train. } \\
\text { resour. }\end{array}$ & $\begin{array}{l}\text { Comm. } \\
\text { benefits }\end{array}$ & $\begin{array}{l}\text { Realis. } \\
\text { time. }\end{array}$ & $\begin{array}{l}\text { Meas. } \\
\text { bench. }\end{array}$ & $\begin{array}{l}\text { Change- } \\
\text { agent } \\
\text { effect. }\end{array}$ & $\begin{array}{l}\text { Workload } \\
\text { adjustment. }\end{array}$ \\
\hline \multicolumn{8}{|l|}{ Respondents' Demographics } \\
\hline \multicolumn{8}{|l|}{ Organizational sector } \\
\hline Public & $0.523^{* *}$ & $0.538^{* *}$ & $0.627 * *$ & $0.618^{* *}$ & $0.747 * *$ & $0.718^{* *}$ & $0.449 * *$ \\
\hline Private & $0.361 * *$ & $0.440 * *$ & $0.465 * *$ & $0.611^{* *} *$ & $0.550 * *$ & $0.613 * *$ & $0.315^{* *}$ \\
\hline \multicolumn{8}{|l|}{ Organization type } \\
\hline Owner/operator & $0.302^{*}$ & $0.447 * *$ & $0.614 * *$ & $0.619 * *$ & $0.644 * *$ & $0.629 * *$ & 0.133 \\
\hline EPC/general contractor & 0.412 & 0.481 & $0.690 * *$ & $0.757 * *$ & $0.625^{*}$ & 0.438 & NA \\
\hline Sub cont./specialty cont. & $0.480^{* *}$ & $0.492 * *$ & $0.408 * *$ & $0.582^{* * *}$ & $0.517 * *$ & $0.687 * *$ & 0.532 \\
\hline $\mathrm{A} / \mathrm{E}$ consultant & 0.259 & $0.541^{*}$ & $0.530^{*}$ & $0.686^{* * *}$ & $0.637 * *$ & $0.681 * *$ & $0.551^{*}$ \\
\hline Facilities manage. \& opera. & $0.654^{*}$ & 0.419 & $0.686^{*}$ & $0.646^{*}$ & $0.686^{*}$ & $0.613^{*}$ & 0.562 \\
\hline \multicolumn{8}{|l|}{ Hierarchical position } \\
\hline Senior executive/VP & 0.231 & $0.537 * *$ & $0.435^{*}$ & $0.627 * *$ & $0.609 * *$ & $0.685^{* * *}$ & 0.248 \\
\hline Regional manager & $0.487 * *$ & $0.479 * *$ & $0.586 * *$ & $0.639 * *$ & $0.621 * *$ & $0.660 * *$ & $0.628 * *$ \\
\hline Project members & 0.295 & $0.475 * *$ & $0.622 * *$ & $0.622 * *$ & $0.765 * *$ & $0.604 * *$ & 0.086 \\
\hline \multicolumn{8}{|l|}{ Years of prof. experience } \\
\hline Less than 10 years & -0.139 & 0.395 & 0.440 & 0.374 & $0.598 *$ & $0.608^{*}$ & 0.241 \\
\hline $10-19$ years & 0.415 & $0.543^{*}$ & $0.639 * *$ & $0.722 * *$ & $0.666 * *$ & $0.738 * *$ & $0.686 * *$ \\
\hline 20-29 years & $0.331^{*}$ & $0.498 * *$ & $0.600 * *$ & $0.648^{* * *}$ & $0.597 * *$ & $0.596^{* * *}$ & 0.260 \\
\hline 30-39 years & $0.487 * *$ & $0.377 *$ & $0.421 * *$ & $0.622 * *$ & $0.459 * *$ & $0.552 * *$ & 0.288 \\
\hline 40 or more years & $0.665^{* * *}$ & $0.584 * *$ & $0.771 * *$ & $0.525^{*}$ & $0.809 * *$ & $0.830 * *$ & 0.721 \\
\hline \multicolumn{8}{|l|}{ Generational affiliation } \\
\hline Baby boomer (1946-1964) & $0.530 * *$ & 0.227 & $0.508 * *$ & $0.613 * *$ & $0.515 * *$ & $0.613 * *$ & $0.402 *$ \\
\hline Generation X (1965-1978) & 0.187 & $0.637 * *$ & $0.462 *$ & $0.666^{* *} *$ & $0.681 * *$ & $0.621 * *$ & $0.430^{*}$ \\
\hline Generation Y (1979-1997) & 0.541 & $0.613^{*}$ & $0.562 *$ & 0.537 & $0.854 * *$ & $0.906 * *$ & 0.406 \\
\hline \multicolumn{8}{|l|}{ Technology Categories } \\
\hline \multicolumn{8}{|l|}{ Technology function } \\
\hline Business-related software & $0.460 * *$ & $0.498 * *$ & $0.637 * *$ & $0.700^{* * *}$ & $0.570 * *$ & $0.657 * *$ & $0.438 * *$ \\
\hline Project-related software & $0.386^{* *} *$ & $0.491 * *$ & $0.330 *$ & $0.521 * *$ & $0.764 * *$ & $0.687 * *$ & 0.247 \\
\hline Physical technology tools & $0.673 * *$ & 0.206 & 0.450 & $0.615^{*}$ & 0.320 & $0.674 * *$ & 0.414 \\
\hline \multicolumn{8}{|l|}{ Technology characteristic } \\
\hline New technology & $0.367 * *$ & $0.434 * *$ & $0.453 * *$ & $0.622 * *$ & $0.435 * *$ & $0.690 * *$ & 0.235 \\
\hline Replacement technology & $0.422 * *$ & $0.493 * *$ & $0.552 * *$ & $0.589 * *$ & $0.699 * *$ & $0.674 * *$ & $0.535^{* *}$ \\
\hline
\end{tabular}

\subsection{Group differences regarding technology functions and characteristics}

The Kruskal-Wallis $\mathrm{H}$ test was conducted to determine whether there are differences in the levels of the CAC based on the technology function: business-related software $(n=75)$, project-related software $(n=57)$, and hardware technology $(n=15)$. The CAC scores for all groups were similar, as assessed by visual inspection of the boxplot .The median CAC scores ranged from -0.0659 for business software to 0.439 for project software to 0.188 
for hardware technology, but the differences were not statistically significant between those groups, $\chi_{2}(3)=1.673$, $p=0.433$. Since the results of the Kruskal-Wallis H test were not statistically significant $(p>.05)$, a post hoc test was not conducted and the null hypothesis for $\mathrm{H} 2 \mathrm{~A}$ was not rejected. The results therefore indicated the CAC is statistically the same across types of technology functions.

The Mann-Whitney U test was conducted to determine whether there were differences in the levels of the CAC based on technology characteristics: new $(n=54)$ and replacement or upgrade $(n=54)$. The CAC scores for both groups were similar, as assessed by visual inspection. The median CAC score for new technology was 0.068 , with a mean rank of 57.4, and the median CAC score for replacement/upgrade technology was 0.068, with a mean rank of 51.6. These scores are not different to a statistically significant degree, $p>0.05, \mathrm{U}=1303, \mathrm{z}=-0.954, p=$ 0.340. Consequently, the null hypothesis for H2B was not rejected; the CAC scores are statistically the same for new technology and replacement/upgrade technology.

\subsection{Group differences regarding respondents' demographics}

The Kruskal-Wallis H test was conducted to determine whether there were differences in the CAC based on respondents' demographical categories. Visual inspection of boxplots for all groups of each demographical category showed that CAC scores for all groups within each demographical category were similar.

For organization type, the following frequencies were collected: owner/operator $(n=47)$, EPC/general contractor $(\mathrm{n}=13)$, subcontractor/specialty contractor $(\mathrm{n}=54)$, architecture/engineering consultant $(\mathrm{n}=21)$, and facilities management and operations $(\mathrm{n}=11)$. The median CAC scores based on organization type were different to a statistically significant degree, $\chi_{2}(4)=9.878, p=0.043$. Pairwise comparisons were performed using Dunn's (1964) procedure with a Bonferroni correction for multiple comparisons ( $p=0.05$, before adjustment). With this calculation, the median CAC scores increased: EPC/general contractor $(-0.0738$, mean rank $=52.3)$, owner/operator $(-0.0685$, mean rank $=64.1)$, architecture/engineering consultant $(0.1876$, mean rank $=74.6)$, facilities management and operations $(0.441$, mean rank $=80.36)$, and subcontractor/specialty contractor $(0.441$, mean rank = 85). The post hoc analysis did not reveal any statistically significant differences in CAC scores for any two group combinations. The non-significant post hoc results can be explained by the weak significance level, $p=0.043$, which is very close to the significance level of 0.05 . Because of the results, the null hypothesis for H3B was rejected; the $\mathrm{CAC}$ is not the same across different organization types.

For job position: senior executive $(n=27)$, regional manager $(n=54)$, and project member $(n=36)$. The median CAC scores were different to a statistically significant degree based on job position, $\chi_{2}(2)=7.885, p=0.019$. Pairwise comparisons were performed using Dunn's (1964) procedure with A Bonferroni correction for multiple comparisons. Statistical significance was accepted at $p<.0166$. This post hoc analysis revealed statistically significant differences in median CAC scores for senior executives $(0.44$, mean rank $=73.1)$ and project members $(0.072$, mean rank $=48.9), p=0.005$, but not between any other group combinations. The median scores and mean ranks were higher for senior executives than for project members, which means that senior executives reported higher levels of successful adoption than did project members. Based on the analysis results, the null hypothesis for $\mathrm{H} 3 \mathrm{C}$ was rejected; the $\mathrm{CAC}$ is not the same across different jobs.

For years of professional experience: less than 10 years $(n=12), 10-19$ years $(n=17), 20-29$ years $(n=59), 30$ 39 years $(n=43)$, and 40 or more years $(n=21)$. The median CAC score was lowest for less than 10 years $(-0.073$, mean rank $=57.3)$, then 20-29 years $(-0.709$, mean rank $=72.8)$, then $10-19$ years $(0.185$, mean rank $=76.8)$, then 30-39 years $(0.185$, mean rank $=81.1)$, and then 40 or more years $(0.441$, mean rank $=88.2)$. However, the differences were not statistically significant, $\chi_{2}(4)=4.692, p=0.320$. Since the results of the Kruskal-Wallis $H$ test were not statistically significant $(p>.05)$, a post hoc test was not conducted. The null hypothesis for H3D was not rejected.

For generational affiliation: baby boomer, born 1946-1964 ( $\mathrm{n}=29)$; generation X, born 1965-1978 $(\mathrm{n}=28)$; and generation Y (born 1979-1997) $(\mathrm{n}=13)$. The CAC median scores were the highest for baby boomers $(0.439$, mean rank $=38.3)$, followed by Generation $Y(0.185$, mean rank $=36)$ and then Generation X $(0.198$, mean rank $=32.4)$. However, the differences were not statistically significant, $\chi_{2}(2)=1.219, p=0.544$. Since the results of the Kruskal-Wallis $\mathrm{H}$ test were not statistically significant $(\mathrm{p}>.05)$, a post hoc test was not conducted. The null hypothesis for H3E was not rejected. 


\section{DISCUSSION}

\subsection{Relationships between OCM practices and change adoption}

The positive bivariate correlations between the seven OCM practices and successful change adoption are consistent with previous findings in the OCM literature. The results are also consistent with recent studies on organizational change adoption in the AEC industry.

The OCM practice that had the strongest positive correlation with change adoption was the utilization of effective change agents. Similarly, previous studies on organizational change indicate that change agents are one of the most important elements of change adoption (Wolpert, 2010) because the change-agent team leads the change and provide essential support during the change (Schweiger and DeNisi, 1991). Additionally, previous studies have emphasized the high importance of change agents in successfully adopting BIM in the AEC industry (Ahn et al. 2016, Lee and Yu 2016).

OCM practices including measured benchmarks, realistic timeframe, and communicated benefits, were also listed among the strongest OCM practices by Lines and Vardireddy (2017). Previous studies have emphasized the importance of such practices in successfully adopting technology change in the AEC industry (Ayinla and Adamu 2018, Liu et al. 2017, Zhou et al. 2019).

The remaining three OCM practices (training resources, senior-leadership commitment and adjusted workload) had moderate correlations with successful change adoption. This aligns with Lines and Vardireddy's (2017) that change-related training and senior-leadership commitment are less significant than other OCM practices. On the other hand, Lines and Smithwick (2019) found that senior-leadership commitment and sufficient resources are among the top-four practices with the strongest correlations with successful change adoption. One explanation for this difference is that Lines and Smithwick's (2019) study data was limited to electrical contractors only.

\subsection{Relationships between respondent demographics and OCM practices}

The correlations between OCM practices and successful change adoption were generally consistent within each category of respondents' demographics, but there were minor differences. For example, CAC scores for the public and private sectors were consistent; all OCM practices had significant correlations with CAC. However, in the organization-type category, the only OCM practices that had strong correlations with successful change adoption for the EPC and general contractor groups were realistic timeframe, training resources, and communicated benefits. One possible explanation for this finding is that because EPC and general contractor organizations are oriented toward cost, time, and productivity, the change is treated as a project and the variables of cost, time, and productivity are their main focuses during the change.

Overall, workload adjustment had the weakest correlation with successful change adoption in this study, but it had one of the three strongest correlations for architecture and engineering consultants, regional managers, and respondents with 10-19 years of professional experience. A potential reason that workload adjustments are more important for these individuals is that they may already be overwhelmed by high workloads or may suffer more in performing their jobs when technology changes are made.

One interesting finding was the lack of significant correlation between senior-leadership commitment and successful change adoption as reported by respondents with 19 or fewer years of professional experience. In contrast, there was a significant correlation between these two variables for groups with 20 or more years of professional experience; the strength of the correlation increased with each increase in years of experience. This finding contradicts one of the findings of Lines and Vardireddy (2017). A potential reason for this contradiction is that this study focused on the adoption of only technology, whereas Lines and Vardireddy did not focus on technology adoption but, rather, examined a wide variety of change type. One possible explanation for the finding of the current study is the less adept technological skills of senior leaders compared to early-career employees (less than 20 years of experience); early-career employees might perceive senior leaders' commitment as generating barriers to implementing the change. Another possible explanation is that early-career employees may perceive that high levels of senior-leadership commitment result in micromanagement approach, thereby causing the earlycareer employees more stress. 
Another interesting observation regarding the reported relationship between OCM practices and the three adoption measurements (Overall Adoption Achieved, Sustainability Long-Term, and Benefits Achieved). Between all OCM practices senior leadership commitment had the only strongest effect on sustainability long-term of change adoption when compared to other two adoption measurements, while other OCM practices reported low effect on sustainability with respect to adoption measurements. Which may indicate that the effective commitment of senior leaders throughout the implementation of technology change will improve the long-term use of the adopted technology throughout the organization.

\subsection{Relationships between technology categories and change adoption}

The function of the adopted technology (business-related software, project-related software, or physical technology tool) was not correlated with change-adoption success. Likewise, the characteristics of the adopted technology (new technology or replacement/upgrade technology) was not correlated with change-adoption success. In other words, the use of organizational-change practices is important in successfully adopting technology of all types.

\subsection{Relationships between respondent demographics and change adoption}

The levels of successful change adoption were statistically different based on organization types and job positions. Though initial analysis indicated that different organization types had different levels of correlation with changeadoption success, further analysis failed to identify which groups combination are statistically different. However, based on the medians and mean ranks of all organization-type groups, it can be ranked as follows, from low to high: EPC/general contractor, owner/operator, architecture/engineering consultant, facilities management and operations, and subcontractor/specialty contractor. A possible explanation of the biggest ranking difference is that specialized organizations (roofing contractors, plumbing contractors, etc.) have more expertise in a specific area than do wide-focused organizations nations (General building contractors, EPC organizations, etc.); specialization in an area eases the process of implementing technologies that are related to the area of expertise. It could be assumed that specialized organizations have a higher likelihood of successfully adopting technology than do unspecialized/wide-focused organizations, although such assumption in based on non-significant difference between any group pairs.

Different groups of job positions reported significantly different levels of change-adoption success. Specifically, senior executives reported higher levels of change-adoption success than did project members. This finding can possibly be explained in three ways. First, senior executives typically observe the implementation of technology on a high level, without low-level details; therefore, their judgment of change-management success may not be as accurate as that of project members. Second, project members typically see the project level of change adoption and therefore will measure success at only a project level. Third, senior executives are better able to observe change adoption throughout the organization and therefore can see how the change affects different areas of the organization and the organization overall; thus, senior executives can determine whether the results align with the objectives of the technology change and whether the adoption is successful overall. All three explanations indicate that the benefits of the change are poorly communicated to lower-level personnel.

\section{CONCLUSION}

\subsection{Contribution}

The study provides several contributions to the literature on organizational change and to practitioners in the AEC industry. This study is the first to focus on OCM practices in relation to adopting technology across the AEC industry as a whole using 167 technology-adoption cases. Other contributions were that the study results indicate that OCM practices are consistent throughout the industry and in line with previous studies, in the sense that the OCM practices were found to have a positive, statistically significant relationship with successful change adoption throughout the AEC industry. Also, the order of correlation strength of OCM practices and successful change adoption were mostly similar to previous studies (i.e. change agent effectiveness having the strongest association with change adoption and other OCM practices with statistically significant relationships). However, relative to other organizational change initiatives common in the AEC industry (such as managerial changes, business process realignment and leadership transitions), successful adoption of new technologies was more strongly associated 
with the OCM practices of measured benchmarks and realistic timeframe. Lastly, only organization type and job position were correlated with levels of change-adoption success; the other five factors (technology function, technology characteristics, sector type, years of professional experience, and generational affiliation) did not have a significant correlation with the level of adoption.

The study results also contribute to practitioners by revealing that there are certain OCM practices that are consistently effective at assisting companies achieve their change adoption objectives for new technologies. These OCM practices all appear to be learnable and repeatable managerial approaches that can become part of a company's skillset. AEC-industry professionals should focus on applying OCM principles, particularly the ones with the highest ranks as shown in Table 7, which represent the strongest correlations with successful change adoption, in order to increase success levels of technology change adoption.

Table 7. Ranked OCM practices for successful technology change adoption

\begin{tabular}{|c|c|c|}
\hline Rank* & OCM practice & Recommendations \\
\hline 1 & Change-agent effectiveness & $\begin{array}{l}\text { The organization should select change agents and provide them with adequate } \\
\text { resources and support to manage the change in the organization. }\end{array}$ \\
\hline 2 & Measured benchmarks & $\begin{array}{l}\text { The organization should establish clear benchmarks to measure the success of the } \\
\text { change adoption. The organization should celebrate when each benchmark is } \\
\text { achieved. }\end{array}$ \\
\hline 3 & Realistic timeframe & $\begin{array}{l}\text { The organization should establish an achievable timeframe for implementing the } \\
\text { change, focusing on long-term adoption rather than on short-term results. }\end{array}$ \\
\hline 4 & Communicated benefits & $\begin{array}{l}\text { The organization should communicate how the change will benefit the } \\
\text { organization overall and employees personally in their specific job functions. }\end{array}$ \\
\hline 5 & Training resources & $\begin{array}{l}\text { The organization should provide required training, so employees have a clear } \\
\text { understanding of the action required to implement the change in their job } \\
\text { functions. }\end{array}$ \\
\hline 6 & Senior-leadership commitment & $\begin{array}{l}\text { The organization's senior leaders should be visibly committed to implementing } \\
\text { the change. }\end{array}$ \\
\hline 7 & Adjusted workload & $\begin{array}{l}\text { The organization should appropriately adjust the workloads of employees involved } \\
\text { in the change, so they can focus on implementing the change. }\end{array}$ \\
\hline
\end{tabular}

\subsection{Limitations and recommendations for future research}

Several study limitations were identified. First, the study is limited by the number of OCM practices since only seven practices were used based on the OCM and AEC literature. Second, while the survey asked participants to identify successful or unsuccessful technology change that their firms had experienced, $80 \%$ of the collected responses represent cases of successful change adoption. The results may have been skewed by this uneven ratio (positive bias). Third, each adoption case was presented from a single point of view; therefore, the data may have been influenced by respondent bias or inaccurate recall of the change adoption. Fourth, the demographic groups were unevenly distributed, which limited the findings about the differences between groups. Fifth, the data were collected from members of the AEC industry only in the United States and Canada, and only involved 167 technology-adoption cases. Finally, this exploratory study is the first to analysis OCM practices of technology adoption in the AEC industry, hence the study is limited regarding factors that may correlate with the levels of change-adoption, factors such as technology types, organization types, employee characteristics, industry trends, driving motivations, level of initial investment, and employee's reaction to change were not considered in this study. Future researches may consider covering the above-mentioned limitations. One important recommendation for future research is to investigate the characteristics and process needed for effective use of the four OCM practices that had strong relationship with successful change adoption.

\section{REFERENCES}

Ahn, Y. H., Kwak, Y. H., and Suk, S. J. (2016). "Contractor's Transformation Strategies for Adopting Building Information Modeling." J. Manage. Eng., 32(1): 05015005.

Ahuja, R., Sawhney, A., and Arif, M. (2018). "Developing organizational capabilities to deliver lean and green project outcomes using BIM." Eng. Constr. Archit. Manage., 25(10): 1255-1276. 
Alvesson, M. (2002). Understanding Organizational Culture, Sage, London.

Antwi-Afari, M. F., Li, H., Pärn, E. A., and Edwards, D. J. (2018). "Critical success factors for implementing building information modelling (BIM): A longitudinal review." Autom. Constr., 91: 100-110.

Arayici, Y., Coates, P., Koskela, L., Kagioglou, M., Usher, C., and O'Reilly, K. (2011). "Technology adoption in the BIM implementation for lean architectural practice." Automation in Construction, 20(2): 189-195. https://doi.org/10.1016/j.autcon.2010.09.016.

Armenakis, A. A., Harris, S. G., and Feild, H. S. (1999). "Making change permanent A model for institutionalizing change interventions." Research in Organizational Change and Development, Emerald Group Publishing Limited, 97-128.

Ayinla, K. O., and Adamu, Z. (2018). "Bridging the digital divide gap in BIM technology adoption." Eng. Constr. Archit. Manage., 25(10): 1398-1416.

Beer, M., and Eisenstat, R. A. (1996). "Developing an Organization Capable of Implementing Strategy and Learning." Human Relations, 49(5): 597-619. https://doi.org/10.1177/001872679604900504.

Bourne, M., Neely, A., Platts, K., and Mills, J. (2002). "The success and failure of performance measurement initiatives: Perceptions of participating managers." International Journal of Operations \& Production Management, 22(11): 1288-1310. https://doi.org/doi:10.1108/01443570210450329.

Bowling, A. (1997). Research methods in health : investigating health and health services, Buckingham; Philadelphia : Open University Press, Buckingham, Philadelphia.

Burnes, B. (2009). Managing Change, Prentice-Hall, London.

Burns, N., and Groves, K. (1997). Practice of nursing research, WB Saunders company, Philadelphia, PA.

Cameron, K. S., and Quinn, R. E. (1999). Diagnosing and changing organizational culture: Based on the competing values framework, John Wiley \& Sons, San Francisco, CA.

Cattell, R. B. (1966). "The scree test for the number of factors." Multivariate behavioral research, 1(2): 245-276

Chang, C.-Y., Pan, W., and Howard, R. (2017). "Impact of Building Information Modeling Implementation on the Acceptance of Integrated Delivery Systems: Structural Equation Modeling Analysis." J. Constr. Eng. Manage., 143(8): 04017044.

Cheng, T., and Teizer, J. (2013). "Real-time resource location data collection and visualization technology for construction safety and activity monitoring applications." Automation in Construction, 34: 3-15. https://doi.org/10.1016/j.autcon.2012.10.017.

Chong, H. Y., Lopez, R., Wang, J., Wang, X., and Zhao, Z. (2016). "Comparative Analysis on the Adoption and Use of BIM in Road Infrastructure Projects." J. Manage. Eng., 32(6): 05016021.

Covin, T. J., and Kilmann, R. H. (1990). "Participant Perceptions of Positive and Negative Influences on LargeScale Change." Group \& Organization Studies, 15(2): 233-248. https://doi.org/10.1177/105960119001500207.

Crew, W. A. (2017). "Best Practices Create Innovation and Improved Competitiveness." J. Constr. Eng. Manage., 143(9): 02517005.

Damanpour, F. (1992). "Organizational Size and Innovation." Organization Studies, 13(3): 375-402.

Delgado-Hernandez, D. J., Cruz-Cruz, C. C., and Vences-García, P. Y. (2017). "Improvement Management Tools in the Construction Industry: Case Study of Mexico." J. Constr. Eng. Manage., 143(4): 05016024.

DeVellis, R. F. (2003). Scale development: theory and applications, Sage, CA.

Dunn, O. J. (1964). "Multiple comparisons using rank sums." Technometrics, 6(3): 241-252.

Eadie, R., Browne, M., Odeyinka, H., McKeown, C., and McNiff, S. (2013). "BIM implementation throughout the UK construction project lifecycle: An analysis." Automation in Construction, 36: 145-151. https://doi.org/10.1016/j.autcon.2013.09.001.

Emiliani, M. L., and Stec, D. J. (2005). "Leaders lost in transformation." Leadership \& Organization Development Journal, 26(5): 370-387. https://doi.org/10.1108/01437730510607862.

Ercan, T. (2019). "New Three-Part Model of Innovation Activity in Construction Companies." J. Constr. Eng. Manage., 145(5): 04019022.

Erdogan, B., Anumba, C. J., Bouchlaghem, D., and Nielsen, Y. (2014). "Collaboration Environments for Construction: Management of Organizational Changes." Journal of Management in Engineering, 30(3): 04014002. https://doi.org/10.1061/(ASCE)ME.1943-5479.0000231.

Field, A. (2009). Discovering statistics using SPSS, Sage, London.

Galpin, T. J. (1996). The human side of change: A practical guide to organization redesign, Jossey-Bass, San Francisco, CA.

Gan, X.-L., Chang, R.-D., Langston, C., and Wen, T. (2019). "Exploring the interactions among factors impeding the diffusion of prefabricated building technologies: Fuzzy cognitive maps." Eng. Constr. Archit. Manage., 26(3): 535-553. 
Garratt, B. (1999). "The Learning Organisation 15 years on: some personal reflections." The Learning Organization, 6(5): 202-207. https://doi.org/10.1108/09696479910299802.

Gholizadeh, P., Esmaeili, B., and Goodrum, P. (2018). "Diffusion of Building Information Modeling Functions in the Construction Industry." J. Manage. Eng., 34(2): 04017060.

Gu, N., and London, K. (2010). "Understanding and facilitating BIM adoption in the AEC industry." Automation in Construction, 19(8): 988-999. https://doi.org/10.1016/j.autcon.2010.09.002.

Gu, N., Singh, V., Taylor, C., London, K., and Brankovic, L. (2010). "BIM adoption: expectations across disciplines." Handbook of research on building information modeling and construction informatics: concepts and technologies, IGI Global, 501-520.

Harty, C. (2005). "Innovation in construction: A sociology of technology approach.” Build. Res. Inf., 33(6), 512522.

Harty, C. (2008). "Implementing innovation in construction: Contexts, relative boundedness and actor-network theory." Constr. Manage. Econ., 26(10): 1029-1041.

Hong, Y., Hammad, A. W. A., Sepasgozar, S., and Akbarnezhad, A. (2019). "BIM adoption model for small and medium construction organisations in Australia." Engineering, Construction and Architectural Management, 26(2): 154-183. https://doi.org/10.1108/ECAM-04-2017-0064.

Hunsucker, J. L., and Loos, D. (1989). "Transition management-An analysis of strategic considerations for effective implementation." Engineering Management International, 5(3): 167-178. https://doi.org/10.1016/S0167-5419(89)80014-6.

Hwang, B.-G., Zhao, X., and Yang, K. W. (2019). "Effect of BIM on Rework in Construction Projects in Singapore: Status Quo, Magnitude, Impact, and Strategies." J. Constr. Eng. Manage., 145(2): 04018125.

Kaiser, H. F. (1974). "An index of factorial simplicity." Psychometrika, 39(1): 31-36.

Kanter, R. M. (1983). The change masters: Innovation for productivity in the American corporation, Simon and Schuster, New York.

Kotter, J. P. (1995). "Leading change: Why transformation efforts fail." 73(2), 59-67.

Lee, S., and Yu, J. (2016). "Comparative Study of BIM Acceptance between Korea and the United States." J. Constr. Eng. Manage., 142(3): 05015016.

Lee, S., Yu, J., and Jeong, D. (2015). "BIM Acceptance Model in Construction Organizations." Journal of Management in Engineering, 31(3): 04014048. https://doi.org/10.1061/(ASCE)ME.1943-5479.0000252.

Lewin, K. (1947). "Frontiers in Group Dynamics:Concept, Method and Reality in Social Science; Social Equilibria and Social Change." Hum. Relat., 1(1): 5-41.

Li, N., and Becerik-Gerber, B. (2011). "Life-Cycle Approach for Implementing RFID Technology in Construction: Learning from Academic and Industry Use Cases." Journal of Construction Engineering and Management, 137(12): 1089-1098. https://doi.org/10.1061/(ASCE)CO.1943-7862.0000376.

Liao, L., and Teo, E. A. L. (2018). "Organizational Change Perspective on People Management in BIM Implementation in Building Projects." Journal of Management in Engineering, 34(3): 04018008. https://doi.org/10.1061/(ASCE)ME.1943-5479.0000604.

Likert, R. (1932). "A technique for the measurement of attitudes." Archives of psychology, 140: 1-55

Lines, B. C., and Reddy Vardireddy, P. K. (2017). "Drivers of Organizational Change within the AEC Industry: Linking Change Management Practices with Successful Change Adoption." J. Manage. Eng., 33(6): 04017031.

Lines, B. C., and Smithwick, J. B. (2019). "Best practices for organizational change management within electrical contractors." International Journal of Construction Education and Research, 15(2): 136-159.

Lines, B. C., Sullivan, K. T., and Wiezel, A. (2015). "Support for organizational change: Change-readiness outcomes among AEC project teams." J. Constr. Eng. Manage., 142(2): 04015062.

Liu, R., Du, J., Issa, R. R. A., and Giel, B. (2017). "BIM Cloud Score: Building Information Model and Modeling Performance Benchmarking." J. Constr. Eng. Manage., 143(4): 04016109.

Loosemore, M. (2014). "Improving construction productivity: a subcontractor's perspective." Eng. Constr. Archit. Manage., 21(3): 245-260.

Loosemore, M., and Cheung, E. (2015). "Implementing systems thinking to manage risk in public private partnership projects." International Journal of Project Management, 33(6): 1325-1334. https://doi.org/10.1016/j.ijproman.2015.02.005.

Lu, Y., Li, Y., Skibniewski, M., Wu, Z., Wang, R., and Le, Y. (2015). "Information and Communication Technology Applications in Architecture, Engineering, and Construction Organizations: A 15-Year Review." Journal of Management in Engineering, 31(1): A4014010. https://doi.org/10.1061/(ASCE)ME.1943-5479.0000319.

Luecke, R. (2003). Managing change and transition, Harvard Business, Boston, MA. 
Ozorhon, B., and Karahan, U. (2017). "Critical Success Factors of Building Information Modeling Implementation." Journal of Management in Engineering, 33(3): 04016054. https://doi.org/10.1061/(ASCE)ME.1943-5479.0000505.

Peansupap, V., and Walker, D. H. T. (2006). "Information communication technology (ICT) implementation constraints: A construction industry perspective." Engineering, Construction and Architectural Management, 13(4): 364-379. https://doi.org/10.1108/09699980610680171.

Schneider, B., Gunnarson, S. K., and Niles-Jolly, K. (1994). "Creating the climate and culture of success." Organizational Dynamics, 23(1): 17-29. https://doi.org/10.1016/0090-2616(94)90085-X.

Schweiger, D. M., and Denisi, A. S. (1991). "Communication with Employees Following a Merger: A Longitudinal Field Experiment." Academy of Management Journal, 34(1): 110-135.

Seo, J., Duque, L., and Wacker, J. (2018). "Drone-enabled bridge inspection methodology and application." Autom. Constr., 94: 112-126.

Sepasgozar, S. M. E., Davis, S., Loosemore, M., and Bernold, L. (2018). "An investigation of modern building equipment technology adoption in the Australian construction industry." Eng. Constr. Archit. Manage., 25(8): 1075-1091.

Slaughter, E. S. (2000). "Implementation of construction innovations." Building Research \& Information, 28(1): 2-17.

Smollan, R. K. (2011). "The multi-dimensional nature of resistance to change." Journal of Management \& Organization, 17(6): 828-849. https://doi.org/10.1017/S1833367200001206.

Spearman, C. (1904). "The proof and measurement of association between two things." Am. J. Psychol., 15(1), $72-101$

Sullivan, K. T. (2011). "Quality Management Programs in the Construction Industry: Best Value Compared with Other Methodologies." Journal of Management in Engineering, 27(4): 210-219. https://doi.org/10.1061/(ASCE)ME.1943-5479.0000054.

Tan, H. C., Carrillo, P. M., and Anumba, C. J. (2012). "Case Study of Knowledge Management Implementation in a Medium-Sized Construction Sector Firm." Journal of Management in Engineering, 28(3): 338-347. https://doi.org/10.1061/(ASCE)ME.1943-5479.0000109.

Tatum, C. B. (1989). "Organizing to Increase Innovation in Construction Firms." Journal of Construction Engineering and Management, 115(4): 602-617. https://doi.org/10.1061/(ASCE)07339364(1989)115:4(602).

Wolpert, C. (2010). "The success of Caterpillar's global approach to change management." Global Business and Organizational Excellence, 29(6): 17-24.

$\mathrm{Xu}, \mathrm{H} .$, Feng, J., and Li, S. (2014). "Users-orientated evaluation of building information model in the Chinese construction industry." Automation in Construction, 39: 32-46. https://doi.org/10.1016/j.autcon.2013.12.004.

Zhang, H., Yan, X., Li, H., Jin, R., and Fu, H. (2019a). "Real-Time Alarming, Monitoring, and Locating for NonHard-Hat Use in Construction." J. Constr. Eng. Manage., 145(3): 04019006.

Zhang, M., Cao, T., and Zhao, X. (2019b). "Using Smartphones to Detect and Identify Construction Worker's Near-Miss Falls Based on ANN." J. Constr. Eng. Manage., 145(1): 04018120.

Zhao, X., Wu, P., and Wang, X. (2018). "Risk paths in BIM adoption: empirical study of China." Engineering, Construction and Architectural Management, 25(9): 1170-1187. https://doi.org/10.1108/ECAM-082017-0169.

Zhou, Y., Yang, Y., and Yang, J.-B. (2019). "Barriers to BIM implementation strategies in China." Eng. Constr. Archit. Manage., 26(3): 554-574. 